\title{
Expectation About Education of Children in Early Age Parent Cooperation
}

\author{
Vevi Sunarti ${ }^{1, *}$ \\ ${ }^{I}$ Department of Non Formal Education, Faculty of Education, Universitas Negeri Padang, Padang, Indonesia \\ *Email: vevisunarti.pls@fip.unp.ac.id
}

\begin{abstract}
Parent cooperation in early childhood education institutions is a determinant of the success of educational goals. Based on the first result of observation show that, parent collaboration with early childhood education institution at Kenagarian Pancung Taba is low, if this problem is not followed up, the purpose of early childhood education in particular is not achieved effectively and efficiently. The purpose of this study is to find description of expatation and parent cooperation and expressing the relationship between these variables. Respondents of this study are parents who have students in early childhood education institutions in Kenagarian Pancung Taba, The research instrument is a questionnaire with a Likert scale model, which has been tested for validity and reliability. The results of this study is indicate that the picture of parents' expectations and cooperation is quite good. From the data analysis shows that significantly the cooperation of parents is influenced by expectations. This fact in general illustrates that there is a relationship of expectations about early childhood education with the collaboration of parents in early childhood education institutions. This implies that in an effort to increase collaboration between parents, it is always necessary to increase expectations for early childhood education institutions. Thus to improve parent cooperation is done by increasing parents' expectations of early childhood education

Keywords: expectation, early childhood education programs, parent cooperation
\end{abstract}

\section{INTRODUCTION}

Lifelong education is everyone's needs because with education throughout human life, it can harmonize the pace of technological development, which is increasingly boundless. Lifelong education is born due to the inability of schooling systems to fulfill basic human needs for education anytime and anywhere. According to Salam[1] lifelong education is the reason of criticisms that give to the school. School education is only limited to the level of education from childhood to adulthood will not meet the requirements needed by the developing world. This everchanging world needs a flexible education system [2].

The famous of lifelong education are nonformal education, formal education pathways and non-formal education channels, which one of them complement each other in developing human resources. Regarding this, Kamil[3] states that all three complement each other especially in (1) fulfilling lifelong learning needs (as long as the community exists), (2) developing lifelong education through integrated formal, informal and non-formal education will facilitate the community in choose education that suits your needs.

Early childhood educations as one of the programs that can realize lifelong education mentioned above is expected to be able to prepare a new human piopener who can compete in the future. Education units are Kindergarten (TK), Child care center(TPA), other early childhood education units. According to Sujiono[4], he position of early childhood education as part of long education, manifested in the form of participation in education which through learning activities by each individual runs throughout life, cannot be used in the school period.

In the year of 2011, the government's target can serve around 18.1 million children to pursue targets rough estimate (APK) Ministry of National Education Renstra was $72.90 \%$ in 2014 (including the APK through the Taman Penitipan Al-Quran , Ministry of Religion). From this target, early childhood education under the guidance of the Ministry of National Education itself is targeted to be able to serve around 7.5 million children through TK, $\mathrm{KB}$, TPA, and other early childhood education units [5]. The implementation of early childhood education functions to foster, grow and develop all the potential of early childhood optimally so that basic behaviors and abilities are formed in accordance with the stages of development in order to have readiness to enter further education in order to achieve national education goals [4]. The sustainability of early childhood education institutions is inseparable from cooperation between existing elements, namely, family, community and government. Good cooperation of all existing elements will produce good results and vice versa the goal will not be achieved if one of the three elements does not work together. Ki Hajar Dewantara stated in Salam[1] that education is a shared responsibility between family, society and government, known as tripusat education. 
The low level of parental cooperation with PAUD institutions is feared to result in not achieving the goals of early childhood education itself, as Patmodewo[7] stated that parental involvement in teaching and learning activities shows their interest in children's education in the classroom. If their parents have a great interest on early childhood education institutions will certainly facilitate the achievement of institutional goals.

Some activities have been made in order to achieve the goals of early childhood education, but there are still many things that are considered to be able to disrupt the smooth learning process. Based on what the researchers got in the field in Kanagarian Pancuang Taba, Kecamatan Bayang Utara the ratio of children to the number of early childhood education is comparable, it is proven that all children can be accommodated by early childhood education institutions.

Interviews conducted by researchers in January 2012 with education service officials and PAUD educators said that, rarely or could it be said, $20 \%$ of parents asked about their child's condition or condition while in school, and $5 \%$ of parents who asked for their child's development $15 \%$ only asks whether the child is crying or not while in early childhood education, which results in every year there are always children who leave before the school year ends, on average more than $49 \%$ of the number of students each year do not take part in activities in early childhood education to completion and most of them leave in the second and third months, only $16 \%$ of parents want to come to discuss the current problem faced by early childhood education institutions if invited to a meeting, and only $2 \%$ of parents want to express their opinion if asked about the way out of the problems being faced and $35 \%$ of early childhood do not attend PAUD.

The above phenomenon indicates the low level of cooperation between parents in the continuation of early childhood education programs. The researcher was interested in seeing the factors that led to the indication of the lack of cooperation between parents of early childhood education institutions. The researcher found factors that influence the low level of cooperation and efforts that can be made to make people want to increase their cooperation with PAUD institutions. All of that is so that the purpose of PAUD can be achieved well. The sustainability of a program is inseparable from the collaboration of the surrounding people, as well as PAUD institutions need collaboration between the educational environment namely, family, community and government [8].

Good cooperation of all existing elements will produce a good goal, otherwise the goal will not be achieved if one of the three elements does not work together. Many factors that can create good cooperation between parents and early childhood education institutions are as stated by Sholeh[9] that knowledge, understanding, perceptions, expectations and attitudes of parents towards early childhood education institutions will shape the creation good cooperation between parents and school.

The purposes of this study are to find: parents' expectation about early childhood education programs; (2) parents' collaboration at early childhood education institution; (3) the significant relationship between parents' expectation about early childhood education with parents' cooperation at early childhood education institution

The hypothesis proposed in this study is: It is estimated that there is a significant relationship between expectations about early childhood education and the cooperation of parents in early childhood education institutions.

\section{METHOD}

This study is included in descriptive correlational research. This study took place at Kanagarian Pancuang Taba, Kecamatan Bayang Utara, Kabupaten Pesisir Selatan. The instrument used was a multiple choice model test and Likert scale model questionnaire. The data of this study were analyzed using regression and correlation techniques. Descriptive analysis to describe the state of each variable

\section{RESULTS AND DISCUSSION}

\subsection{Result}

Parents's Expectation About Early Childhood Education The results of these calculations show that the average, median and mode scores do not exceed the standard deviation. This means that the frequency distribution of parents 'expectations of variable scores on early childhood education in Kenagarian Pancuang Taba tends to be normal, with respondents' achievement rates (TCR) of $62.55 \%$ and belonging to the fairly good category. This shows that parents' expectations for early childhood education in Kenagarian Pancung Taba according to respondents are sufficient.

The data of this study were analyzed using correlation and regression techniques, this technique can be used only if certain conditions are met. According to Sudjana[10] the intended requirements are that: 1) data sourced from predetermined samples, 2) data originating from populations that are normally distributed, 3) population groups have homogeneous variances, 4) between independent variables do not correlate significantly and the link between the independent variable and the dependent variable forms a linear line.

This study proposes a hypothesis which one the first and second hypotheses are tested using correlation techniques and simple regression.

Parents' expectations for early childhood education are included in the fairly good category, which is equal to $62.55 \%$ of the ideal score. From the results of testing the second hypothesis, the expectation variable is significantly related to parents in early childhood education institutions. This means the expectation relationship that has a relationship with parents at early childhood education institutions with coordination $(\mathrm{Ry} 2)=0.338$ and $\rho 0.025$ $(<0.05)$, with the form of the relationship that corresponds to the relationship $\hat{\mathrm{Y}}=14.929+0.598 \mathrm{X} 2$. The 
determination coefficient (R2) is 0.114 . This shows that the contribution of the role increases in the participation of parents, with a contribution of $11.4 \%$. This means that the better the expectations of parents in early childhood education institutions, the better the cooperation of parents, and vice versa if parents do not have hope for early childhood education for the development of children, then the work done will also increase tend to increase.

\subsection{Discussion}

Efforts that can be made in increasing parent cooperation in early childhood education institutions are through increasing parents' expectations about early childhood education, that is by trying to encourage parents to be actively involved in various activities such as socialization, counseling, seminars related to children's education early age, it is expected that these activities can increase parents' expectations about early childhood education which results in increased parental cooperation in early childhood education institutions [11].

The results of the 2001 State Minister for Women's Empowerment in the Jakarta and surrounding areas, as reported by the Kita and Buah Hati Foundation [12], stated that in general the community viewed that education was not needed for early childhood. This is reasonable considering that people's understanding of the importance of early childhood education is still very low and in general they are of the view that education is synonymous with school, so education for early childhood is deemed not necessary.

The findings above indicate that in general parents' expectations of early childhood education institutions are at a fairly good level. If parents have great expectations of early childhood education for the development of their children in adulthood, then naturally there will be increased cooperation in early childhood education institutions and education goals will be achieved well. However, if parents do not have/have high expectations for early childhood education, it will naturally lower parents' cooperation in early childhood education. Therefore, managers, teachers or interested parties should increase parents' expectations for early childhood education, in order to create good cooperation between parents and institutions [13]. The results of this study are supported by the opinion of Irene[9] arguing that: Characteristics of parents, for example farmers, fishermen, traders, employees and others will color the condition and quality of schools. Differences in the character of parents make their hopes for school especially graduation different. Therefore schools must establish relationships, collaborate with parents of students".

Chattermole \& Robinson[9] suggested the reason for the importance of parent and school cooperation is that teachers must know the needs and expectations of children and parents who attend pre-school education. Based on the above, it can be concluded that parents' expectations about early childhood education have a great influence on the success of children. The higher the expectations of parents about early childhood education, the greater the cooperation of parents in early childhood education institutions. Mangkunegara[14] suggests that for parents, sending children to school is an obligation accompanied by hopes that cyanak can gain insight, a new world, a life of socialization, the core sciences in order to prepare them to face their future with well.

Data analysis shows that significantly the cooperation of parents in early childhood education institutions is influenced by expectations about early childhood education. This fact generally illustrates that there is a relationship of understanding and expectations about early childhood education with the collaboration of parents in early childhood education institutions, both individually and jointly. Thus to improve parent cooperation in early childhood education institutions can be done by increasing parents' expectations for early childhood education. Soemiarti[9] several things have proven that it turns out that more parents realize the importance of school programs, the more direct and large the involvement of parents. Furthermore, in the study that was considered relevant, Dedi Erianti 2010 with the title of the relationship between parents' understanding of education in early childhood education institutions and their participation in entering or not entering early childhood education institutions in Kelurahan Balai Nan Duo Kota Payakumbuh by the results of the study there is a significant relationship between parents' understanding of education in early childhood education institutions with their participation in entering or not excluding children into early childhood education institutions [9].

Parents' expectations about early childhood education have a meaningful influence on the sustainability of national education goals, especially the goals of early childhood education. The aim of early childhood education according to Hasan[15] can be formulated as follows. (1) Providing care and guidance that allows early childhood to grow and develop according to their age and potential. (2) Identify possible irregularities, so that if there is a deviation, early intervention can be done. (3) Providing a diverse and exciting experience for early childhood, which enables them to develop potential in various fields, so that they are ready to attend education at the elementary school level.

Early childhood education is prepared to shape children in preparing and welcoming the next phase in a child's future life, the determination of children when they become adults is influenced by the factors given when he was at an early age.

Considering the important role of early childhood education towards the formation of adult humans later, then it should have received serious attention from all existing elements, families (parents) as a place to lay the foundation of education for children who should have understood and had hope for early childhood education, thus the golden period for a child will be passed well, with the hope that when adults grow up, children can adjust to the conditions. 
[3] M. Kamil, Pendidikan Non Formal, Pengembangan Melalui Pusat Kegiatan Belajar Masyarakat. Bandung: CV. Alfabeta, 2009.

\subsection{Conclusion}

The conclusion of the result this study are : (1) parents' expectation about early childhood education in the category are quite good, this means that parents have expectations or expectations that are good enough for their children in gaining insight, living in socializing and gaining knowledge about preparing for the future if their children enter into childhood education institutions early. (2) The cooperation of parents towards early childhood education institutions in the category is quite good, this means that parents have sufficient cooperation both for early childhood education institutions in terms of task orientation, process orientation and development orientation. (3) Expectations about early childhood education are significantly related to parent cooperation, meaning parents' hopes for their children in gaining insight, socializing life and gaining knowledge of preparing for the future have a significant effect on parents in terms of orientation to the task, orientation to the process and orientation in development.।

\subsection{Suggestion}

Based on research of this study, same suggestion can be stated as follows: (1) Parents who have early childhood to always create good collaboration with early childhood education institutions, in the form of orientation to the task, orientation to the process and orientation to development because with the involvement of parents can monitor and fill the golden period in children to grow child development can be passed well. educators and managers of early childhood education, in order to foster an understanding of the nature, goals, benefits, functions and importance of early childhood education and expectations related to hoping to gain insight, live socialize and gain knowledge about preparing for the future, because more parents understand and have high expectations for early childhood education so it will be able to create good cooperation between parents and the school. This can be done by holding meetings with parents of students both at school and home visits where parents do not have much time due to daily activities by explaining the importance of early childhood education.

\section{REFERENCES}

[1] B. Salam, Pengantar Pedagogik. Bandung: Rineka Cipta, 1996.

[2] H. Darmadi, Pengantar Pendidikan Era Globalisasi: Konsep Dasar,Teori, Strategi dan Implementasi dalam Pendidikan Globalisasi. Denpasar: An1mage, 2019.
[4] Y. N. Sujiono, Konsep Dasar Pendidikan Anak Usia Dini. Jakarta: Indeks, 2009.

[5] Kementerian Pendidikan Nasional, "Pedoman Penyelenggaraan Program Pendidikan Anak Usia Dini, Nonformal Dan Informal Dirjen PAUDNI," Indonesia, 2011.

[6] S. Patmonodewo, Pendidikan Anak Prasekolah. jakarta: Rineka Cipta, 2008.

[7] S. Padmodewo, Pendidikan Anak Prasekolah. Jakarta: Rineka Cipta, 2003.

[8] S. Syuraini, S. Setiawati, and V. Sunarti, "Penyusunan Program Parenting Bagi Pengelola dan Pendidik PAUD di Nagari Lubuk Jantan Kecamatan Lintau Buo Utara," Kolok. J. Pendidik. Luar Sekol., vol. 6, no. 2, pp. 112-118, 2018.

[9] V. Sunarti, "Pemahaman dan Ekspektasi tentang Pendidikan Anak Usia Dini dengan Kerjasama Orang Tua," Pedagog. J. Ilm. Ilmu Pendidik., vol. XIII, no. 1, pp. 40-46, 2013.

[10] Sudjana, Metode Statistika. Bandung: Tarsito, 1992.

[11] N. Arifiyanti, "Kerjasama antara Sekolah dan Orang Tua Siswa di TK se-kelurahan Triharjo Sleman," J. Pendidik. Guru Pendidik Anak Usia Dini, vol. 6, no. 4, 2015.

[12] F. Jalal, "Meningkatkan Kesadaran Masyarakat Akan Pentingnya PAUD," Bul. Padu J. Ilm. Anak Usia Dini, vol. 03, pp. 9-18, 2002.

[13] F. Jalal and S. Dedi, Reformasi Pendidikan dalam Konteks Otonomi. Yogyakarta: Adicitra Karya Nusa, 2001.

[14] A. P. Mangkunegara, Sumber Daya Manusia. Jakarta: PT. Prenhallindo, 2003.

[15] M. Hasan, Pendidikan Anak Usia Dini. Yogyakarta: Diva Press, 2009. 